\title{
MAKNA KEPEMILIKAN MASYARAKAT DALAM PRIVATISASI BERDASARKAN UNDANG-UNDANG NOMOR 19 TAHUN 2003 TENTANG BADAN USAHA MILIK NEGARA
}

\author{
Oleh: Martahan Martin Purba \\ Alumni Program Studi Doktor Ilmu Hukum \\ Program Pascasarjana Universitas Islam Bandung \\ Email: martinpurba_sh@yahoo.co.id
}

\begin{abstract}
Abstrak
Pasal 74 Ayat (1) huruf a Undang-Undang Nomor 19 Tahun 2003 tentang Badan Usaha Milik Negara (BUMN) ditentukan bahwa privatisasi dilakukan dengan maksud memperluaskan kepemilikan masyarakat atas Persero. Tetapi, makna memperluas kepemilikan masyarakat dalam undang-undang ini tidak tegas (multi tafsir), sehingga dapat menimbulkan persoalan dalam pelaksanaannya. Berdasarkan hal tersebut makna memperluas kepemilikan masyarakat sebagai konsekuensi dan esensi dari dilakukannya privatisasi menjadi menarik untuk diteliti. Metode penelitian ini adalah yuridis normatif, sedangkan sifat penelitian ini tergolong kepada penelitian eksploratif. Sumber data yang digunakan adalah data sekunder terdiri dari bahan hukum primer, sekunder dan tersier selanjutnya dianalisis data dilakukan secara kualitatif. Hasil akhir penelitian ini ditarik kesimpulan dengan menggunakan metode berfikir deduktif. Hasil penelitian ini dapat dijelaskan bahwa makna memperluas kepemilikan masyarakat dalam privatisasi BUMN berdasarkan Undang-Undang Nomor 19 Tahun 2003 tentang BUMN tidak tegas (multi tafsir). Agar privatisasi sejalan dengan maksud memperluas kepemilikan masyarakat maka harus ditentukan kriterianya. Dengan tidak tegasnya makna memperluas kepemilikan masyarakat menyebabkan privatisasi tidak seperti yang digambarkan oleh pemerintah, bertujuan untuk memperluas kepemilikan masyarakat. Namun, bukanlah masyarakat secara keseluruhan, tetapi hanya kelompok masyarakat khusus, yakni mereka yang punya uang (investor lokal atau asing) atau dengan kata lain memperluas kepemilikan pribadi bagi pemodal.
\end{abstract}

\begin{abstract}
Article 74 Paragraph (1) letter a of Law Number 19 of 2003 on State-Owned Enterprises (SOES) determined that privatization is done with the intention of extending community ownership Limited. However, extending the meaning of community ownership in this law does not expressly (multiple interpretations), which can cause problems in the implementation. Based on the above meanings expand public ownership as a consequence and the essence of privatization be interesting to study. This research method is normative, whereas the nature of this study pertained to exploratory research. Source data used are secondary data consists of primary legal materials, secondary and tertiary data were then analyzed qualitatively. The final results of this study be concluded by using deductive thinking. The results of this study can be explained that the meaning of expanding the community ownership in privatization pursuant to Act No. 19 of 2003 on SOEs is not firm (multiple interpretations). To be consistent with the intent of expanding the
\end{abstract}


privatization of public ownership it must be determined criteria. By not specifically expand the meaning of community ownership led to privatization is not as portrayed by the government, aiming to expand public ownership. However, not society as a whole, but only particular groups of people, namely those who have money (local or foreign investor) or in other words extending private ownership to the investor.

\section{Kata kunci: Makna, Kepemilikan, BUMN, Privatisasi}

\section{Pendahuluan}

Pasal 33 Undang-Undang Dasar (UUD) Negara Republik Indonesia Tahun 1945 merupakan landasan konstitusional perekonomian nasional. Salah satu yang berperan dalam perekonomian nasional adalah Badan Usaha Milik Negara (BUMN). Peran penting BUMN bukan hanya diharapkan sebagai pengemban kepentingan dan pelayanan serta pemenuhan kebutuhan rakyat banyak, tetapi juga sebagai penyumbang terbesar dalam perekonomian nasional. ${ }^{1}$ Hal itu dapat dilihat secara nyata melalui peranannya selaku perintis kegiatan usaha-usaha (pioneer), ${ }^{2}$ dalam perekonomian nasional.

Secara ekonomi, Indonesia pernah menjadi negara yang disegani di Asia Tenggara. Namun, setelah krisis 1997 ekonomi Indonesia mengalami keterpurukan. Berbagai upaya yang disarankan International Monetary Fund (IMF) telah dijalankan, misalnya format Anggaran Pendapatan Belanja Negara (APBN) dari T-Account menjadi I-Account, yang memungkinkan adanya defisit pada APBN. Salah satu upaya yang ditempuh Pemerintah untuk menutup defisit anggaran tersebut adalah melakukan privatisasi BUMN. ${ }^{3}$
Tujuan privatisasi saat terjadi krisis tersebut lebih diarahkan untuk memenuhi kebutuhan keuangan negara. Strategi utama privatisasi BUMN dilakukan dengan divestiture (divestasi), yaitu cara pengalihan aset Pemerintah yang terdapat pada BUMN kepada pihak lain. Sampai dengan pertengahan tahun 1997 Pemerintah telah berhasil melakukan privatisasi saham minoritas atas kepemilikan saham mayoritas yang dimiliki Pemerintah pada sejumlah BUMN termasuk penawaran saham perdana untuk 6 perusahaan, yaitu Telkom, Indosat, Tambang Timah, Aneka Tambang, Semen Gresik, dan BNI. Proses privatisasi terus berlanjut, pada tahun 1998-1999 dilakukan privatisasi atas sejumlah perusahaan termasuk Semen Gresik, Telkom (lanjutan), Pelindo, Indosat, Kimia Farma, Bank Mandiri, dan lainnya. ${ }^{4}$

Secara teori privatisasi membantu terbentuknya pasar bebas, mengembangnya kompetisi kapitalis yang oleh para pendukungnya dianggap akan memberikan harga yang lebih kompetitif kepada publik. Sebaliknya, para sosialis menganggap privatisasi sebagai hal yang negatif, karena memberikan layanan penting untuk publik dan mengakibatkan kualitas

${ }^{1}$ Harsono, Kerja Sama Antara Perusahaan Negara, Swasta, dan Koperasi Dalam Rangka Menyukseskan Pembangunan Ekonomi di Indonesia, Pidato Pengukuhan dalam penerimaan jabatan Guru Besar, Universitas Brawijaya, Malang, 1986, hlm. 2.

${ }^{2}$ Rudhi Prasetya dan Neil Hamilton, dalam Aminuddin IImar, Hak Menguasai Negara dalam Privatisasi BUMN, (Jakarta: Kencana Prenada Media Group, 2012), hlm. 70. hlm. 391.

${ }^{3}$ Benhard Limbong, Ekonomi Kerakyatan dan Nasionalisme Ekonomi, (Jakarta: Margareta Pustaka),

${ }^{4}$ Asropi, Menilik Kinerja Privatisasi : Perbandingan Malaysia dan Indonesia, Jurnal Administrator Borneo, Volume 4, Nomor 2, 2008, hlm. 13. 
layanan yang buruk, akibat penghematanpenghematan yang dilakukan oleh perusahaan untuk mendapatkan profit. ${ }^{5}$

Profitisasi yang mengarah kepada privatisasi BUMN baik berupa divestasi total maupun yang partial, di mata publik selalu memiliki dimensi ganda, pro dan kontra. Dimensi ganda itu tergantung pada perspektif dan mazhab perekonomian yang dianut oleh suatu bangsa. Penganut mazhab sosialisme pasti tidak setuju dengan privatisasi. Argumentasinya berkisar pada kepentingan tenaga kerja dan kepentingan negara. Dalam suatu Pemerintahan di mana partai sosialis menjadi mayoritas, agenda kebijakan penjualan perusahaan negara, pasti tidak ada. Lain halnya negara yang bermazhab liberalisme, pasti setuju privatisasi. Argumennya berkisar pada pasar bebas, efisiensi dan minimalis intervensi Pemerintah. Penganut mazhab liberal, menganggap di tangan swasta produktivitas lebih efisien dan menguntungkan. Swastalah sebagai pemegang kendali produksi, Pemerintah cukup hanya sebagai regulator. Pihak yang tidak setuju privatisasi selalu berpandangan bahwa BUMN bukan hanya mesin uang, tetapi juga sebagai agent of development dan agent of social change.

Berdasarkan hasil penelitian Sokarina mengemukakan realitas sosial dan politik terjadi pro kontra ketika wacana privatisasi. ${ }^{6}$ Para pendukung kebijakan privatisasi berangkat dari asumsi dan fakta, birokrasi Pemerintah (public sector) di manapun cenderung tidak efisien, tidak inovatif, high cost, poor level of service, tidak berorientasi kepada customer, melainkan kepada atasan. Sementara itu, private sector cenderung sebaliknya lebih efisien, inovatif dan berorientasi kepada customer. Institusi dengan watak negatif seperti itu, jika diserahkan untuk mengelola unit usaha akan mengurangi kinerja unit usaha tersebut. ${ }^{7}$

Pihak yang setuju dengan privatisasi BUMN berargumen bahwa privatisasi perlu dilakukan untuk meningkatkan kinerja BUMN serta menutup defisit APBN. Dengan adanya privatisasi diharapkan BUMN akan mampu beroperasi secara lebih profesional. Alasannya, dengan privatisasi di atas $50 \%$ maka kendali dan pelaksanaan kebijakan BUMN akan bergeser dari Pemerintah ke investor baru. ${ }^{8}$ Contohnya PT Indosat sebagai salah satu BUMN yang sejak akhir tahun 2008 saham Pemerintah Indonesia tinggal $14,3 \%$, selebihnya 65 persen dikuasai oleh Qtel (Pemerintah Qatar). Sebagai pemegang saham terbesar, investor tentu berupaya bekerja secara efisien sehingga mampu menciptakan laba yang optimal. Meskipun dikelola secara efisien, eksistensinya diharapkan mampu menyerap tenaga kerja yang lebih banyak serta mampu memberikan konstribusi yang lebih baik kepada Pemerintah melalui pembayaran pajak dan pembagian dividen.

Pihak yang tidak setuju dengan privatisasi beragumen bahwa apabila privatisasi tidak dilaksanakan maka kepemilikan BUMN tetap di tangan Pemerintah. Dengan demikian, segala keuntungan maupun kerugian sepenuhnya ditanggung oleh Pemerintah. Mereka

${ }^{5}$ Benhard Limbong, Ekonomi Kerakyatan...Op.Cit., hlm. 397.

${ }^{6}$ Ayu Sokarina, Menggagas Dimensi Kinerja Perusahaan Berdasarkan Perspektif Politcal Ekonomy of Accounting, Makalah Dalam Simposium Nasional Akuntansi XIV Aceh 2011 Universitas Syah Kuala Banda Aceh 21-22 Juli 2011, hlm. 3.

${ }^{7}$ Sunarsip, Pro Kontra Privatisasi BUMN, Penulis adalah Director of Economic Affairs Center for Indonesian Reform (CIR) Republika Selasa, 08 Oktober 2002.

${ }^{8}$ Pramudya, Neoliberal, Restrukturisasi \& Privatisasi BUMN, https://pramudyasikumbang. wordpress.com/2012/05/20/neoliberal-restrukturisasi-privatisasi-bumn/, diakses pada 30 Oktober 2015. 
beragumentasi bahwa defisit anggaran harus ditutup dengan sumber lain, bukan dari hasil penjualan BUMN. Mereka memprediksi bahwa defisit APBN akan terjadi pada tahun-tahun mendatang. Apabila BUMN dijual setiap tahun untuk menutup defisit APBN, suatu ketika BUMN akan habis terjual dan defisit APBN pada tahuntahun mendatang tetap akan terjadi.

Pihak yang kontra seperti Sri Edi Swasono mengemukakan meski tidak diprivatisasi BUMN sesungguhnya bisa menjadi agent of development, bisa menjadi the leading sector, bahkan menyediakan jasa publik (benefit center) dan meraih laba (profit center) sekaligus. Asalkan, Pemerintah bisa menyewa manajer-manajer profesional dalam taraf apapun dan mengadakan aliansi-aliansi strategis dengan siapapun. ${ }^{9}$

Selain Sri Edi Swasono, penolakan juga datang dari Revrisond Baswir untuk memperbaiki kinerja BUMN yang diperlukan bukan menjual BUMN tersebut melainkan mereformasi metode pengelolaan BUMN dan meningkatkan kesadaran kritis rakyat terhadap hak serta kewajiban-kewajiban mereka sebagai warga negara. ${ }^{10}$

Revrisond Baswir merupakan pengamat ekonomi dari Universitas Gadjah Mada (UGM) mengingatkan nasionalisme Indonesia harus mengacu pada Pasal 33 Ayat (2) UUD Negara Republik Indonesia Tahun 1945 yang menyatakan cabang-cabang produksi yang penting bagi negara dan yang menguasai hajat hidup orang banyak dikuasai oleh negara. Jika privatisasi dilakukan, akan terjadi rasionalisasi terhadap buruh dan komersialisasi aset-aset yang menyangkut hidup orang banyak. Harga- harga pun akan dikendalikan pemilik modal asing. ${ }^{11}$

Penguasaan modal asing dibanyak sektor ekonomi strategis di Indonesia sudah menjadi fakta yang tak dapat dibantah. Misalnya, kebijakan Bank Indonesia yang membiarkan masuknya bank-bank asing dengan mudah untuk membeli bank-bank lokal (Bank EkonomiHSBC, Bank NISP-OCBC dan seterusnya). Selain itu, telah banyak BUMN yang telah privatisasi. Melihat kondisi ini banyak kalangan menilai negara ini sudah seperti rumah tanpa pintu dan jendela. Siapa saja boleh datang, masuk dan mengambil kekayaan dan membawanya pergi ke luar rumah. ${ }^{12}$

Dalam konteks itu, perlu dipertegas tentang nasionalisme ekonomi Indonesia yang mengacu pada Pancasila (sila ke-5) dan UUD Negara Republik Indonesia Tahun 1945 (Pasal 33) sebagai koridor negara dalam mengimplementasikan kebijakan ekonomi, khususnya terkait investasi asing. ${ }^{13}$ Pasal 33 UUD Negara Republik Indonesia Tahun 1945 adalah ideologi ekonomi nasional untuk mengelola sumbersumber ekonomi negara yang memberikan manfaat yang sebesar-besarnya bagi kesejahteraan rakyat. Prespektif pertumbuhan dan kesejahteraan ekonomi masyarakat bertalian erat dengan konsep memaknai nasionalisme ekonomi memanfaatkan sumbersumber ekonomi negara bagi sebesarbesarnya kemakmuran rakyat.

Pasca privatisasi terhadap PT Telkom Pemerintah mengesahkan Undang-Undang Nomor 19 Tahun 2003 tentang Badan Usaha Milik Negara menggantikan undang-undang sebelumnya, yaitu Undang-Undang Nomor 9

${ }^{9}$ Dalam Sunarsip, Pro Kontra...Loc. Cit.

${ }^{10} /$ bid.

${ }^{11} \mathrm{http}: / /$ eknomi.inilah. com / read/ detail/888562/ berbahaya -nasionalisme-ekonomi-gita-wirjawan, terakhirkali diakses 17 Oktober 2015.

${ }^{12}$ lbid.

${ }^{13}$ A. Mukthie Fadjar, Pasal 33 UUD 1945, HAM, dan UU SDA, Jurnal Konstitusi, Volume 2, Nomor 2, September 2005, hlm. 7. 
Tahun 1969 tentang Penetapan Peraturan Pemerintah Pengganti Undang-Undang Nomor 1 Tahun 1969 tentang Bentuk-Bentuk Usaha Negara menjadi Undang-Undang.

Menurut Pasal 74 Ayat (1) huruf a ditentukan bahwa privatisasi dilakukan dengan maksud memperluaskan kepemilikan masyarakat atas Persero. Tetapi, makna memperluas kepemilikan masyarakat dalam undangundang ini tidak tegas (multi tafsir), sehingga dapat menimbulkan persoalan dalam pelaksanaannya. Dengan makna yang tidak tegas maka maksud privatisasi tersebut bisa dinikmati masyarakat tanpa batas (lokal maupun asing). Hal ini karena tidak ada kriteria dan pembatasan.

Tidak tegasnya makna memperluas kepemilikan masyarakat menyebabkan privatisasi tidak seperti yang digambarkan oleh Pemerintah, yakni bertujuan untuk meningkatkan peran serta masyarakat dalam kepemilikan saham perusahaan negara/BUMN. Namun, bukanlah masyarakat secara keseluruhan, tetapi hanya kelompok masyarakat tertentu, yaitu mereka yang punya uang (investor). Sampai saat ini privatisasi masih menjadi perdebatan karena dinilai belum mendatangkan manfaat bagi masyarakat. ${ }^{14}$

Berdasarkan uraian di atas maka makna memperluas kepemilikan masyarakat sebagai konsekuensi dan esensi dari dilakukannya privatisasi menjadi menarik untuk diteliti.

\section{Metode Penelitian}

Penelitian hukum pada dasarnya adalah kegiatan penyelesaian masalah. Adapun cara pemecahan masalah dilakukan penulis dengan mengidentifikasi masalah pada akhirnya dianalisis melalui suatu metode penelitian sehingga dapat dipertanggungjawabkan secara ilmiah.

\section{Metode pendekatan}

Menurut Soetandyo Wignyosoebroto metode pengkajian hukum adalah cara untuk mencari jawaban yang benar mengenai permasalahan tentang hukum. ${ }^{15}$ Maka konsep hukum yang jelas akan amat menentukan metode yang tepat dan layak dipakai. Pendekatan penelitian ini adalah penelitian hukum yuridis normatif. Menurut Soerjono Soekanto sebagaimana dikemukakan oleh Burhan Ashofa, bentuk penelitian yuridis normatif itu dapat berupa: ${ }^{16}$

"a. Inventarisasi hukum positif;

b. Penemuan asas hukum;

c. Penemuan hukum in concreto;

d. Perbandingun hukum; dan

e. Sejarah hukum".

Penelitian yuridis normatif dinamakan juga dengan penelitian hukum normatif atau penelitian hukum doktrinal. Sehubungan dengan tipe penelitian yuridis normatif, pertimbangan bahwa titik tolak penelitian adalah mengenai makna kepemilikan masyarakat berdasarkan Undang-Undang Nomor 19 Tahun 2003 tentang Badan Usaha Milik Negara".

\section{Sifat penelitian}

Menurut Johnny Ibrahim penelitian hukum normatif ini adalah untuk menghasilkan ketajaman analisis hukum yang didasarkan pada doktrin dan norma-norma yang telah ditetapkan dalam sistem hukum baik yang telah tersedia sebagai bahan hukum maupun yang dicari sebagai bahan kajian guna memecahkan

\footnotetext{
${ }^{14}$ Safri Nugraha dkk, Privatisasi Perusahaan Milik Negara ditinjau Dari UUD 1945, (Jakarta: Badan Pembinaan Hukum Nasional, 2011), hlm. 10.

${ }^{15}$ Soetandyo Wignyosoebroto, Konsep Hukum, Tipe Kajian, dan Metode Penelitiannya, (Surabaya: Universitas Airlangga, tanpa tahun), hlm. 7-9.

${ }^{16}$ Burhan Ashofa, Metode Penelitian Hukum, (Jakarta: Rineka Cipta, 1996), hlm. 14.
} 
problem hukum faktual maka tidak ada jalan lain berkenalan dengan ilmu hukum normatif sebagai ilmu hukum praktis normologis dan mengandalkan penelitian hukum normatif. ${ }^{17}$ Sesuai dengan pendekatan yang dipilih maka sifat penelitian ini tergolong kepada penelitian eksploratif yang memuat gambaran terhadap setiap identifikasi masalah sekaligus dilakukan analisis secara terperinci terhadap setiap permasalahan.

\section{Sumber dan teknik pengumpulan data}

\section{a. Sumber data}

Bahan-bahan hukum penelitian yuridis normatif sebagai pendekatan utama di atas diperoleh dari pustaka-pustaka baik secara manual maupun online dan lain sebagainya. Sumber data penelitian yang digunakan merupakan data sekunder yang terdiri dari:

1). Bahan hukum primer

Bahan hukum primer, yakni bahan hukum yang bersumber dari peraturan perundang-undangan dalam ruang lingkup hukum positif. Bahan hukum primer ini adalah bahan hukum yang bersifat autoratif artinya mempunyai otoritas. Bahan hukum primer terdiri dan peraturan perundang-undangan yang diurut berdasarkan hirarki dan putusan pengadilan ${ }^{18}$ seperti yang terdapat dalam Undang-Undang Dasar 1945, Undang-Undang Nomor 19 Tahun 2003 tentang Badan Usaha Milik Negara.

2). Bahan hukum sekunder

Bahan sekunder, yaitu bahan hukum yang memberikan penjelasan terhadap bahan hukum primer, yang bukan merupakan dokumen resmi, seperti: buku-buku teks, hasil-hasil penelitian, pendapat para sarjana, artikel, jurnal ilmiah, hasil-hasil seminar atau pertemuan ilmiah lainnya yang relevan dengan penelitian ini.

3). Bahan hukum tersier

Bahan hukum tersier, yaitu bahan hukum yang memberikan petunjuk atau penjelasan terhadap bahan hukum primer berupa surat kabar, majalah, dan lainnya yang relevan dan dapat dipergunakan untuk melengkapi data yang diperlukan dalam penelitian ini.

\section{b. Teknik pengumpulan data}

Teknik pengumpulun data dilakukan dengun teknik kepustakaan (library research) atau studi dokumenter yang secara aktif dilakukan penulis terhadap sumber-sumber hukum dan sumber bacaan yang berhubungan dengan topik penelitian ini, seperti: peraturan perundang-undangan, buku-buku hukum, makalah hukum, artikel dan lain-lain sebagainya yang memiliki hubungan dengan permasalahan yang diteliti.

\section{Teknik analisis}

Penelitian ini data dianalisis secara kualitatif, yaitu cara menganalisis data yang diambil dari peraturan perundang-undangan, konsep, teori, pandangan pakar serta data lainnya yang seluruhnya relevan dengan masalah pokok yang diteliti dan disajikan secara deskriptif, yang berbentuk uraian kalimat atau rangkaian kata-kata, dan bukan dalam bentuk angka-angka. Hasil akhir penelitian ini ditarik

${ }^{17}$ Jony Ibrahim, Teori dan Metodologi Penelitian Hukum Normatif, (Surabaya: Bayu Media Publishing, 2006), hlm. 73.

${ }^{18} \mathrm{Ibid}, \mathrm{hlm} .141$. 
kesimpulan dengan menggunakan metode berfikir deduktif, yakni menarik kesimpulan dari hal-hal yang bersifat umum kepada hal-hal bersifat khusus.

\section{Pembahasan \\ Makna Memperluas Kepemilikan Masya- rakat Dalam Privatisasi Badan Usaha Milik Negara Berdasarkan Undang-Undang Nomor 19 Tahun 2003 tentang Badan Usaha Milik Negara}

Cikal bakal privatisasi Indonesia tujuan awalnya mulia, yakni membangkitkan ekonomi negara di tengah minimnya modal dalam negeri. Privatisasi disisi lain merupakan kepemilikan perusahaan negara kepada rakyatnya (bukan kepada asing) secara tidak langsung memang merupakan implementasi dari ekonomi kekeluargaan (koperasi).

Privatisasi terhadap BUMN di Indonesia saat ini landasan hukumnya adalah UndangUndang Nomor 19 Tahun 2003. Dalam undangundang ini diatur tentang bagaimana cara meningkatkan kinerja perusahaan negara yang diatur mulai dari restrukturisasi perusahaan. Dasar privatisasi terhadap BUMN yang diatur dalam Undang-Undang Nomor 19 Tahun 2003 tentang BUMN tersebut menurut penulis terdapat ketentuan yang belum jelas sebagaimana dapat dilihat pada penggunaan kata-kata berikut:

1. Pasal 74: menciptakan struktur dan manajemen keuangan yang baik/kuat; Persero berdaya saing; memperluas kepemilikan masyarakat.

2. Pasal 75: memperhatikan prinsip-prinsip transparansi, kemandirian, akuntabilitas, pertanggungjawaban, dan kewajaran.

3. Pasal 77: kegiatan kepentingan masyarakat.

4. Pasal 80: mengundang pihak yang dipandang perlu.

5. Pasal 84: benturan kepentingan.
6. Pasal 85: wajib menjaga kerahasiaan informasi sepanjang informasi belum terbuka.

Selain kelemahan pada penggunaan kata yang berakibat peluang dan kendala program privatisasi dengan jumlah hanya 13 pasal untuk sebuah kebijakan Pemerintah terkait aset negara yang jumlahnya sangat besar, tentunya pengaturan ini tidak cukup jelas, apalagi bila dikaitkan dengan sistem pertanggungjawaban publik pada rakyat melalui wakilnya. Tetapi, tidak ada satu peraturan pun yang mengatur mengenai hal itu.

Fokus penulis terhadap ketentuan yang belum jelas tentang privatisasi dalam UndangUndang Nomor 19 Tahun 2003 tentang BUMN adalah sehubungan dengan makna memperluas kepemilikan masyarakat sebagaimana disebutkan pada Pasal 74 Ayat (1) huruf a, yang berbunyi: (1) Privatisasi dilakukan dengan maksud untuk : a. memperluas kepemilikan masyarakat atas Persero". Dalam penjelasan Pasal 74 tersebut menjelaskan sebagai berikut:

"Dengan dilakukannya privatisasi diharapkan akan terjadi perubahan atas budaya perusahaan sebagai akibat dari masuknya pemegang saham baru, baik melalui penawaran umum (go public) ataupun melalui penyertaan langsung (direct placement). Perusahaan akan dihadapkan pada kewajiban pemenuhan persyaratan-persyaratan keterbukaan (disclosure) yang merupakan persyaratan utama dari suatu proses go public, atau adanya sasaran-sasaran perusahaan yang harus dicapai sebagai akibat masuknya pemegang saham baru. Budaya perusahaan yang berubah tersebut akan dapat mendorong peningkatan kinerja perusahaan yang selanjutnya akan dapat mempertinggi daya saing perusahaan dalam 
berkompetisi dengan pesaing-pesaing, baik nasional, regional, bahkan global sehingga pada akhirnya akan dapat memberikan konstribusi yang lebih besar terhadap perekonomian nasional dalam bentuk barang dan jasa yang semakin berkualitas dan terjangkau harganya, serta penerimaan negara dalam bentuk pajak yang akan semakin besar pula.

Dengan demikian maksud dan tujuan privatisasi pada dasarnya ..dst...dst".

Memperhatikan Penjelasan di atas memperluas kepemilikan masyarakat ditujukan dalam hal pemilikan perseroan dengan masuknya pemegang saham baru, baik melalui penawaran umum (go public) ataupun melalui penyertaan langsung (direct placement). Namun, undang-undang tersebut tidak secara jelas (multi tafsir) dalam menentukan apa yang dimaksud dengan memperluas kepemilikan masyarakat. Apakah masyarakat yang dimaksud orang saja atau termasuk juga suatu badan? Kemudian apakah masyarakat yang dimaksud hanya domestik atau termasuk juga asing.

Makna memperluas kepemilikan masyarakat yang tidak jelas menurut penulis merupakan celah hukum sehingga yang dimaksudkan undang-undang bisa melenceng dari tujuan yang seharusnya. Tujuan privatisasi menurut undang-undang adalah memperluas kepemilikan masyarakat, tetapi bisa saja yang terjadi adalah memperluas kepemilikan pribadi dari orang tertentu. Memperluas kepemilikan pribadi (individual) berseberangan dengan memperluas kepemilikan masyarakat (sosial).

Selain itu, bisa juga terjadi bukannya memperluas kepemilikan masyarakat domestik, tetapi memperluas kepemilikan masyarakat asing. Kemungkinan tersebut bisa terjadi, karena tidak adanya batasan yang jelas tentang masyarakat yang dimaksud oleh pembuat undang-undang.
Maksud privatisasi untuk memperluas kepemilikan masyarakat sebagaimana ditentukan Pasal 74 huruf a Undang-Undang Nomor 19 Tahun 2003 tersebut menurut penulis harus sejalan dengan metode yang dilakukan negara dalam melakukan privatisasi. Ada beberapa metode yang digunakan oleh suatu negara untuk memprivatisasi BUMN, diantaranya:

"1. Penawaran saham BUMN kepada umum (public offering of shares). Penawaran ini dapat dilakukan secara parsial maupun secara penuh. Di dalam transaksi ini, Pemerintah menjual sebagian atau seluruh saham kepemilikannya atas BUMN yang diasumsikan akan tetap beroperasi dan menjadi perusahaan publik. Seandainya Pemerintah hanya menjual sebagian sahamnya maka status BUMN itu berubah menjadi perusahaan patungan Pemerintah dan swasta. Pendekatan semacam ini dilakukan oleh Pemerintah agar mereka masih dapat mengawasi keadaan manajemen BUMN patungan tersebut sebelum kelak diserahkan sepenuhnya kepada swasta.

2. Penjualan saham BUMN kepada pihak swasta tertentu (private sale of share). Di dalam transaksi ini, Pemerintah menjual seluruh ataupun sebagian saham kepemilikannya di BUMN kepada pembeli tunggal yang telah diidentifikasikan atau kepada pembeli dalam bentuk kelompok tertentu. Privatisasi dapat dilakukan penuh atau secara sebagian dengan kepemilikan campuran. Transaksinya dapat dilakukan dalam berbagai bentuk, seperti akuisisi langsung oleh perusahaan lain atau ditawarkan kepada kelompok tertentu. Cara ini 
juga sering disebut sebagai penjualan strategis (strategic sale) dan pembelinya disebut investor strategis.

3. Penjualan aktiva BUMN kepada swasta (sale of government organization state-owned enterprise assets). Pada metode ini, pada dasarnya transaksi adalah penjualan aktiva, bukan penjualan perusahaan dalam keadaan tetap beroperasi. Biasanya jika tujuannya adalah untuk memisahkan aktiva untuk kegiatan tertentu, penjualan aktiva secara terpisah hanya alat untuk penjualan perusahaan secara keseluruhan.

4. Penambahan investasi baru dari sektor swasta ke dalam BUMN (new private investment in an state-owned enterprise assets). Pada metode ini, Pemerintah dapat menambah modal pada BUMN untuk keperluan rehabilitasi atau ekspansi dengan memberikan kesempatan kepada sektor swasta untuk menambah modal. Dalam metode ini, Pemerintah sama sekali tidak melepas kepemilikannya, tetapi dengan tambahan modal swasta maka kepemilikan Pemerintah mengalami dilusi (pengikisan). Dengan demikian, BUMN itu berubah menjadi perusahaan patungan swasta dengan Pemerintah. Apabila pemilik saham mayoritasnya adalah swasta maka BUMN itu telah berubah statusnya menjadi milik swasta.

5. Pembelian BUMN oleh manajemen atau karyawan (management/ employee buy out). Metode ini dilakukan dengan memberikan hak kepada manajemen atau karyawan perusahaan untuk mengambilalih kekuasaan atau pengendalian perusahaan. Keadaan ini biasanya terkait dengan perusahaan yang semestinya dapat efektif dikelola oleh sebuah manajemen, namun karena campur tangan Pemerintah membuat kinerja tidak optimal".

Dari beberapa metode tersebut UndangUndang Nomor 19 Tahun 2003 tentang BUMN di dalam Pasal 78 hanya membolehkan tiga cara dalam privatisasi:

“1. Penjualan saham berdasarkan ketentuan pasar modal.

2. Penjualan saham langsung kepada investor.

3. Penjualan saham kepada manajemen dan/atau karyawan yang bersangkutan".

Berdasarkan alternatif metode privatisasi, yang paling sering digunakan adalah penawaran saham BUMN kepada umum (public offering of shares), yaitu privatisasi dengan melakukan penjualan saham kepada pihak swasta melalui pasar modal, penjualan saham BUMN kepada pihak swasta tertentu (private sale of share), yaitu penjualan saham BUMN kepada satu atau sekelompok investor swasta, dan melalui pembelian BUMN oleh manajemen atau karyawan (management/ employee buy out), yaitu penjualan saham BUMN kepada pihak karyawan atau manajemen BUMN.

Dari ketiga cara dalam privatisasi di atas yang sejalan dengan maksud Pasal 74 huruf a Undang-Undang Nomor 19 Tahun 2003, yaitu memperluas kepemilikan masyarakat adalah cara penawaran saham BUMN kepada umum (public offering of shares), yaitu privatisasi dengan melakukan penjualan saham kepada pihak swasta melalui pasar modal. Tetapi, memperluas kepemilikan masyarakat ini tidak jelas sehingga merupakan celah hukum untuk memperluas kepemilikan pribadi dan celah hukum memperluas kepemilikan orang asing. 
Terkait penjualan saham BUMN kepada umum dengan melakukan penjualan saham kepada pihak swasta melalui pasar modal landasan hukumnya saat ini adalah Peraturan Menteri Keuangan Nomor 153 /PMK.010/2010 tentang Kepemilikan Saham dan Permodalan Perusahaan Efek. Menurut Pasal 3 Ayat (1) peraturan ini ditentukan bahwa "Dalam hal Perusahaan Efek nasional atau patungan melakukan Penawaran Umum maka saham Perusahaan Efek tersebut dapat dimiliki seluruhnya oleh Pemodal Dalam Negeri atau Pemodal Asing". Berdasarkan Pasal 3 Ayat (1) Peraturan Menteri Keuangan Nomor 153 / PMK.010/2010 tersebut jelaslah bahwa baik perusahaan efek tersebut dapat dimiliki seluruhnya oleh pemodal dalam negeri atau pemodal asing. Landasan ini menjadi dasar yang kuat bagi masyarakat asing untuk memiliki saham BUMN yang diprivatisasi dengan cara penjualan saham melalui pasar modal.

Dengan makna memperluas kepemilikan masyarakat yang tidak jelas tersebut maka sasaran yang diinginkan bisa saja tidak tercapai. Sementara Pemerintah tidak menentukan secara tegas makna kepemilikan masyarakat sebagaimana dimaksud pada Pasal 74 huruf a Undang-Undang Nomor 19 Tahun 2003. Kekaburan makna itu merupakan pintu masuk yang lebar bagi kepentingan masyarakat asing (pemodal asing) semata.

Apalagi dari segi politis, masih banyak pihak yang kontra terhadap kebijakan privatisasi yang dimanfaatkan pihak asing. Pasalnya, kebijakan ini dinilai tidak sesuai dengan prinsip-prinsip nasionalisme. Privatisasi kepada pihak asing dinilai akan menyebabkan terbangnya keuntungan BUMN kepada pihak asing, bukannya kembali kepada rakyat Indonesia. ${ }^{19}$

Tentang tidak jelasnya makna memperluas kepemilikan masyarakat sejalan dengan fenomena yang disinggung dalam bab pendahuluan, yaitu menyebabkan privatisasi tidak seperti yang digambarkan oleh Pemerintah, bertujuan untuk meningkatkan peran serta masyarakat dalam kepemilikan saham perusahaan negara/BUMN. Namun, ternyata yang dimaksud masyarakat di sini bukanlah masyarakat secara keseluruhan, tetapi tentu saja hanya kelompok masyarakat khusus, yakni mereka yang punya uang (investor). Sampai saat ini privatisasi masih menjadi perdebatan karena dinilai belum mendatangkan manfaat bagi masyarakat. ${ }^{20}$

Berdasarkan analisis ini penulis berpendapat agar privatisasi sejalan dengan maksud memperluas kepemilikan masyarakat sebagaimana disebutkan pada Pasal 74 huruf a maka rumusan makna memperluas kepemilikan masyarakat harus ditentukan siapa masyarakat dimaksud? Setidaknya masyarakat tersebut ditentukan dengan kriteria minimal sebagai berikut:

1. Orang-orang yang berkewarganegaraan Indonesia;

2. Badan usaha swasta nasional yang dimiliki oleh orang yang berkewarganegaraan Indonesia.

Setelah dibahas makna memperluas kepemilikan masyarakat di atas, pembahasan selanjutnya adalah model privatisasi mana yang sesuai dengan iklim perekonomian, politik dan sosial budaya Indonesia haruslah mempertimbangkan faktor-faktor seperti: ${ }^{21}$

"1. Ukuran nilai privatisasi.

${ }^{19}$ Marwah M. Diah, Restrukturisasi BUMN di Indonesia Privatisasi atau Korporatisasi, (Jakarta: Literata Jendela Dunia IImu, 2003), hlm. 133.

${ }^{20} \mathrm{Ibid}$.

${ }^{21} \mathrm{Ibid}$. 
2. Kondisi kesehatan keuangan tiga tahun terakhir.

3. Waktu yang tersedia bagi BUMN untuk melakukan privatisasi.

4. Kondisi pasar.

5. Status perusahaan, apakah telah go public atau belum.

6. Rencana jangka panjang masingmasing BUMN".

Dari tiga metode privatisasi BUMN yang sering digunakan seperti yang telah dikemukakan di atas, yang dianggap relatif sesuai dengan kondisi BUMN dewasa ini adalah penawaran saham BUMN kepada umum dan pembelian BUMN oleh manajemen atau karyawan. Pasalnya, dengan metode penjualan saham BUMN kepada pihak swasta tertentu berarti akan ada pemusatan kepemilikan pada satu atau sekelompok pihak swasta saja. Hal ini kurang sesuai dengan jiwa demokrasi ekonomi yang menghendaki pemerataan kesejahteraan dan tidak sejalan dengan maksud yang ditentukan Pasal 74 tentang memperluas kepemilikan masyarakat. Selain itu, pemusatan kepemilikan pada satu atau sekelompok pihak atas BUMN akan sangat berbahaya jika pihak yang bersangkutan mengeksploitisir BUMN untuk kepentingan keuntungan semata.

Dengan penawaran saham BUMN kepada umum maka kepemilikan BUMN akan jatuh ke tangan rakyat. Hal ini sesuai dengan jiwa demokrasi ekonomi. Karena dengan demikian maka akan dapat dicapai pemerataan kesejahteraan kepada rakyat Indonesia melalui pemerataan saham pada publik, sedangkan dengan pembelian BUMN oleh manajemen atau karyawan, pemerataan pun dapat dicapai. Akan tetapi, pemerataan kepemilikan hanya akan terjadi pada karyawan dan manajemen BUMN. Namun, cara ini masih dianggap lebih baik dari pada kepemilikan BUMN jatuh ke tangan pihak asing.

Kelebihan dari mekanisme penawaran umum (initial publik offering/IPO) adalah memungkinkan terwujudnya usaha transparansi dan pengawasan masyarakat (public security) karena pasar modal dimanapun akan mensyaratkan setiap perusahaan go public. Dengan memakai salah satu metode privatisasi BUMN, yaitu initial public offering maka BUMN harus menjual sahamnya di pasar perdana (primary market).

Bila metode kebijakan privatisasi BUMN adalah IPO maka di luar undang-undang dan peraturan yang terkait langsung dalam kebijakan privatisasi BUMN terdapat tambahan 6 (enam) peraturan perundang-undangan yang terkait langsung dengan program privatisasi BUMN melalui penjualan saham di pasar modal Indonesia. Dasar hukum bisnis dan peraturanperaturan ini juga berlaku sama (equal) bagi perusahaan-perusahaan yang akan melakukan go public, yaitu: (1) Undang-Undang Nomor 8 Tahun 1995 tentang Pasar Modal; (2) Kitab Undang-Undang Hukum Perdata (KUHPer); (3) Kitab Undang-Undang Hukum Pidana (KUHP); (4) Undang-Undang Nomor 5 Tahun 1999 tentang Larangan Praktik Monopoli dan Persaingan Tidak sehat; (5) Peraturan Pemerintah Nomor 46 Tahun 1995 tentang Penyelenggaraan Kegiatan di Pasar Modal; (6) Peraturan Pemerintah Nomor 46 Tahun 1995 tentang Tatacara Pemeriksaan di Pasar Modal.

Lahirnya Undang-Undang Nomor 8 Tahun 1995 tentang Pasar Modal yang mulai berlaku efektif sejak tanggal 1 Januari 1996 dimaksudkan untuk mengakomodasikan keempat persyaratan pokok tersebut. Secara hukum perdata dan hukum bisnis penerapan Undang-Undang Pasar Modal dapat dijadikan guidance bagi kebijakan privatisasi BUMN melalui penjualan saham di pasar modal.

Aspek hukum dalam proses go public BUMN memang sejak semula sangat terkait dengan perkembangan dan dinamisnya pergerakan sektor finansial. Karena itu aspek hukum sangat diharapkan untuk dapat 
memainkan peranan nyata dalam menarik investasi di pasar modal. Potret dari kedinamisan aspek hukum dilihat dengan jelas dalam interaksi antara perusahaan terbuka (Tbk) dibandingkan dengan perusahaan biasa, lewat proses going public atau going private. Hanya saja, dalam proses interaksi tersebut, di samping prosesnya yang normal dan wajar, terselip pula trik-trik bisnis finansial, yang demi mengejar keuntungan seketika sering melakukan pelanggaran hukum. Karena itu, aspek hukum dituntut untuk dapat memandang masalah ini dengan jeli dengan sejauh mungkin meminimalkan loop hole yang mungkin digunakan oleh pihak-pihak yang tidak bertanggung jawab dengan menentukan persyaratan yang ketat dan pengawasan yuridis secara komprehensif.

Prosedur dan persyaratan berdasarkan ketentuan peraturan pasar modal yang sekarang telah berlaku tidaklah terlalu ringan, namun juga belum dapat dikatakan bahwa peraturan yang ada sudah memadai bagi perkembangan pasar modal dan masih perlu disempurnakan. Dalam pelaksanaannya, aspek hukum bisnis yang perlu diperhatikan dalam pendewasaan pasar modal Indonesia tanpa memberatkan atau meringankan persyaratan go public, yaitu yang menyangkut persyaratan pokok dalam hukum perdata yang berlaku di mana dalam pelaksanaan perjanjian adalah itikad baik atau "good faith atau goede trow". Kaitan persyaratan ini dalam kegiatan pasar modal serta pada lembaga penunjangnya (dalam arti luas) banyak terlihat pada aktifitas institusi dan profesi penunjang pasar modal, seperti peranan notaris, penasehat hukum, konsultan emiten. ${ }^{22}$

Secara makro ekonomi kebijakan dan strategi reformasi BUMN harus didukung oleh sektor keuangan yang kuat baik dalam negeri (domestik) maupun dukungan sektor keuangan luar negeri (internasional). Dari studi kepustakaan dapat interpretasikan bahwa keberhasilan dan kegagalan kebijakan privatisasi BUMN dibeberapa negara sangat tergantung kepada kesiapan dan dukungan sektor keuangan, baik domestik maupun internasional. Pemerintah yang dapat mendorong secara kondusif sektor dan institusi keuangan mempunyai peluang untuk melihat keberhasilan program privatisasi yang dicanangkan, sebaliknya bila sektor dan institusi keuangan di negara tersebut tidak dikembangkan oleh kebijakan Pemerintahnya maka dapat dipastikan bahwa program privatisasi BUMN menjadi tidak berhasil. Bila dilihat dari aspek hukum bisnis, BAPEPAM sebagai institusi Pemerintah dan otoritas pasar modal yang sekarang melebur ke Otoritas Jasa Keuangan (OJK) telah diberi kewenangan yang besar (Undang-Undang Nomor 8 Tahun 1995 tentang Pasar Modal) dalam membina, mengatur dan mengawasi kegiatan bursa, hal ini mengingat pasar modal merupakan sumber pembiayaan bagi perusahaan atau BUMN privatisasi maupun sarana investasi bagi para investor.

Fungsi pengawasan dapat dilakukan baik secara preventif dengan membuat peraturan, pedoman pembimbingan dan pengarahan, sedangkan pengawasan secara represif dengan melakukan pemeriksaan, penyidikan dan pengenaan sanksi jika terdapat indikasi dan bukti yang kuat atas pelanggaran ketentuan Undang-Undang Pasar Modal. Dari aspek hukum bisnis Undang-Undang Pasar Modal merupakan alat kontrol sosial agar kebijakan dan mekanisme yang berjalan di pasar modal dipatuhi oleh pelaku ekonomi. Oleh hukum kontrol sosial tersebut dijalankan dengan menggerakkan berbagai aktivitas yang melibatkan penggunaan kekuasaan negara ${ }^{23}$ hlm. 35.

${ }^{22}$ Kartini Mulyadi, Aspek Hukum Dalam Mendewasakan Pasar Modal Indonesia, (Jakarta: ISEI, 1999), 
sebagai suatu institusi yang diorganisisir secara politik.

Berkaitan dengan kebijakan privatisasi BUMN diharapkan Undang-Undang Pasar Modal dapat menjadi guidance bagi institusi Pemerintah, sektor dan institusi keuangan, pelaku ekonomi di pasar modal dan institusi dan profesi penunjang lainnya dalam mendorong keberhasilan program privatisasi melalui penjualan saham BUMN di pasar modal Indonesia.

Dalam privatisasi masyarakat atau investor yang membeli saham diprioritaskan berasal dari karyawan, rakyat banyak melalui investment fund, public, institutional investor, finansial investor, dan strategic investor. Dengan variasi investor ini memungkinkan saham negara terdilusi, tetapi masih menjadi mayoritas. Penjualan saham kepada strategik investor menimbulkan risiko kemungkinan terjadinya KKN, walaupun itu dilakukan dengan cara tender terbuka, praduga negatif akan tetap muncul. Dalam proses tender ini, faktor akses ke pemutus menjadi salah satu kunci dalam memenangkan tender.

Penelitian yang lain mengkaji implementasi kebijakan privatisasi BUMN dilakukan oleh Djalil. Penelitian yang menjadi disertasinya menghasilkan kesimpulan bahwa terdapat lima faktor yang menyebabkan tidak tercapainya target privatisasi BUMN, yaitu: ${ }^{24}$

Pertama, pembahasan internal Pemerintah yang melibatkan banyak instansi/ departemen, termasuk Sekneg untuk membuat peraturan Pemerintah tentang BUMN yang diprivatisasi, membutuhkan waktu yang cukup lama. Kedua, proses persetujuan di DPR juga memerlukan waktu yang cukup lama karena proses politik yang sulit diprediksi, alot, dan menyangkut berbagai macam kepentingan serta panjangnya mekanisme yang harus didahului berdasarkan tatib DPR. Ketiga, waktu pelaksanaan yang tidak kondusif sehingga terpaksa dilakukan penundaan privatisasi, hal ini terkait dengan aspek teknis, terutama situasi pasar. Keempat, resistensi dari BUMN itu sendiri pada masa lalu. Contohnya kasus PT Krakatau Steel, PT Angkasa Pura II, dan PT Pelindo, di mana manajemen enggan melakukan privatisasi karena berbagai kepentingan. Kelima, faktor eksternal, seperti kasus Enron tahun 2001, pemboman World Trade Center (WTC) di Amerika Serikat tahun 2001, subprime mortgage (kasus kredit perumahan di AS) tahun 2007, meningkatnya harga minyak bumi dan kasus-kasus besar secara global lainnya yang berdampak pada waktu pelaksanaan privatisasi.

Pembahasan selanjutnya adalah bagaimana pembaharuan hukum privatisasi BUMN sebagai bagian penting dari konstribusi penelitian ini. Pembaharuan yang dimaksud adalah merujuk pendapat Stan Ross yang mengatakan bahwa pembaharuan hukum adalah sebuah proses di mana hukum diubah ke arah hukum yang berisikan nilai-nilai dan kebutuhan masyarakat. ${ }^{25}$ Bagaimana cara atau means mencapai pembaharuan hukum tersebut? Jawabannya, cara yang paling tepat adalah melalui suatu evaluasi baik (substansi) perundang-undangan maupun struktur hukum dan lain-lain. Evaluasi hukum ini bertujuan agar

\footnotetext{
${ }^{23}$ Kekuasaan negara dapat dikategorikan dalam lingkup hukum publik dan perdata lihat Winahyu Erwiningsih, Pelaksanaan Pengaturan Hak Menguasai Negara Atas Tanah Menurut UUD 1945, Jurnal Hukum, Nomor Edisi Khusus Volume, 16 Oktober 2009, hlm. 122.

${ }^{24}$ Djalil dalam A Habibullah, Kebijakan Privatisasi BUMN, http://ahabibullah.wordpress.com/2010/01/ 17/ kebijakan- privatisasi-bumn-relasi-state-market-and-civil-society/, terakhir kali diakses 11 Oktober 2015.

${ }^{25}$ Albert Hasibuan, Pembaruan Substansi Hukum di Era Pemerintahan Susilo Bambang Yudhoyono, dalam Dialek Pembaruan Sistem Hukum Indonesia, (Jakarta: Sekretariat Jenderal Komisi Yudisial Republik Indonesia, 2012), hlm. 134-135.
} 
pembaharuan atau reformasi hukum menjadi tepat dan efektif.

Pemerintah Indonesia mendirikan BUMN dengan dua tujuan utama, yaitu tujuan yang bersifat ekonomi dan tujuan yang bersifat sosial. Dalam tujuan yang bersifat ekonomi, BUMN dimaksudkan untuk mengelola sektor-sektor bisnis strategis agar tidak dikuasai pihak-pihak tertentu. Bidang-bidang usaha yang menyangkut hajat hidup orang banyak, seperti perusahaan listrik, minyak dan gas bumi, sebagaimana diamanatkan dalam Pasal 33 UUD Negara Republik Indonesia 1945, semestinya dikuasai oleh BUMN. Dengan adanya BUMN diharapkan dapat terjadi peningkatan kesejahteraan masyarakat, terutama masyarakat yang berada di sekitar lokasi BUMN. Tujuan BUMN yang bersifat sosial antara lain dapat dicapai melalui penciptaan lapangan kerja serta upaya untuk membangkitkan perekonomian lokal. Penciptaan lapangan kerja dicapai melalui perekrutan tenaga kerja oleh BUMN.

Berdasarkan Pasal 33 UUD Negara Republik Indonesia Tahun 1945 Ayat (1) maka sistem ekonomi yang dianut Indonesia adalah sistem ekonomi yang berdasar atas asas kekeluargaan. Konsep sistem ekonomi yang demikian di Indonesia disebut sebagai konsep demokrasi ekonomi. Mubyarto menyebutkan bahwa dalam konsep demokrasi ekonomi sistem ekonomi tidak diatur oleh negara melalui perencanaan sentral (sosialisme), akan tetapi dilaksanakan oleh, dari dan untuk rakyat. ${ }^{26}$ Demokrasi ekonomi mengutamakan terwujudnya kemakmuran masyarakat (bersama) bukan kemakmuran individu-individu. Demokrasi ekonomi mengartikan masyarakat harus ikut dalam seluruh proses produksi dan turut menikmati hasil-hasil produksi yang dijalankan di Indonesia.

Mengacu pada Pasal 33 UUD Negara Republik Indonesia Tahun 1945, tersirat bahwa poin utama dari perekonomian Indonesia adalah kesejahteraan rakyat. Di sinilah peran demokrasi ekonomi, yaitu sebagai pemandu pengelolaan BUMN agar dapat memaksimalkan kesejahteraan rakyat. BUMN harus dapat beroperasi dengan efektif dan efisien, sehingga dapat menyediakan produk-produk vital yang berkualitas dengan harga yang terjangkau bagi rakyat. Selain itu, BUMN juga harus berupaya memperbaiki profitabilitasnya, sehingga dapat diandalkan sebagai sumber pendanaan utama bagi Pemerintah, terutama untuk mendanai defisit anggarannya. Hal ini akan sangat berpengaruh pada kesejahteraan rakyat, karena BUMN tidak lain adalah pengelola sumber daya yang vital bagi hajat hidup rakyat banyak, sehingga tentu akan sangat merugikan rakyat jika BUMN jatuh bangkrut atau pailit.

Praktik privatisasi BUMN yang dilakukan oleh Pemerintah Indonesia dianggap sebagai jalan keluar yang paling baik untuk melaksanakan amanat demokrasi ekonomi untuk menyehatkan BUMN di Indonesia dalam rangka peningkatan dan pemerataan kesejahteraan rakyat. Pada beberapa BUMN, ada yang diprivatisasi oleh pihak asing, bahkan dalam jumlah kepemilikan saham yang cukup signfikan. ${ }^{27}$ Privatisasi BUMN kepada pihak asing ini dinilai "menggadaikan" nasionalisme Indonesia. Selain itu, BUMN tidak lain adalah pihak yang diberikan wewenang khusus untuk mengelola sumber daya vital yang memegang hajat hidup orang banyak. Menurut Pasal 33 UUD Negara Republik Indonesia Tahun 1945,

\footnotetext{
${ }^{26}$ Dewi Hanggraeni, Apakah Privatisasi BUMN Solusi yang Tepat Dalam Meningkatkan Kinerja?, Jurnal Manajemen Usahawan Indonesia, Nomor 6 Tahun 2009, hlm. 33.

${ }^{27} /$ bid.
} 
sumber daya yang seperti demikian itu harus dikelola oleh negara.

Bila dilihat dari sudut pandang Pasal 33 UUD Negara Republik Indonesia Tahun 1945, tampak bahwa sebenarnya privatisasi BUMN kepada pihak asing agak kontradiktif dengan jiwa pasal ini. Pihak asing yang bersangkutan jelas bertindak atas nama swasta yang tentu saja bertindak dengan didorong oleh maksud dan motif hanya untuk mencari keuntungan yang maksimal. Jika demikian yang terjadi, BUMN yang diprivatisasi kepada pihak asing hanya akan menjadi keuntungan bagi pihak asing, sehingga dapat dikatakan manfaatnya akan berpindah kepada pihak asing, bukannya ke rakyat Indonesia.

Secara kuantitatif maupun kualitatif Indonesia pada dasarnya tidak kekurangan produk hukum, tetapi masih sangat lemah dalam penegakkan hukumnya (law enforcement). Ketentuan-ketentuan mengenai corporate governance pada dasarnya secara langsung sudah termaktub dalam UndangUndang Perbankan, Undang-Undang Perseroan Terbatas, Undang-Undang Pasar Modal, Undang-Undang BUMN maupun produk hukum lainnya, tetapi sisi lain secara fair harus diakui bahwa selama ini masing-masing otoritas belum mampu melaksanakan penegakan hukum (law enforcement) secara optimal. Selain itu, struktur pemilikan korporasi yang terkonsentrasi dan mempunyai hubungan historis yang erat dengan kepentingan pejabat Pemerintah belum dapat dikikis sepenuhnya, sehingga menghambat diberlakukannya sistem legal yang fair, equal treatment dan berkembangnya lingkungan serta etika bisnis (business envinronments) yang sehat.

Pengalaman pelaksanaan governance yang buruk, krisis ekonomi yang berkelanjutan, serta kesadaran akan semakin kompetitifnya perdagangan dunia telah menyadarkan Pemerintah untuk segera menata kembali ekonominya. Tinjauan persyaratan yuridis bagi perusahaan untuk go public, bersumber dari perundangan-undangan dari berbagai bidang, yaitu: (1) Undang-Undang Perseroan Terbatas Nomor 40 Tahun 2007 (UU PT) beserta peraturan pelaksanaannya; (2) Perundangundangan di bidang Pasar Modal; dan (3) Perundang-undangan di bidang lainnya. Data dan informasi mengenai penegakan hukum (law enforcement) yang terjadi di pasar modal Indonesia akan berpengaruh kepada tingkat investasi yang diharapkan, hal ini tentunya akan menjadi beban berat bagi target dan perolehan dana segar dari BUMN yang melakukan penjualan saham di pasar modal Indonesia.

Menurut Munir Fuady diakui bahwa peraturan mengenai pasar modal di Indonesia masih sederhana untuk suatu pasar yang complicated, akan tetapi lebih disayangkan lagi peraturan yang simple itu belum sepenuhnya ditegakkan, sehingga dapat dikatakan law enforcement masih sangat lemah. Hal ini teridentifikasi tidak gencarnya kasus yang sampai ke pengadilan (pidana, perdata maupun tata usaha negara), berkaitan dengan pasar modal hal ini menjadi indikasi kuat betapa law enforcement bidang pasar modal di Indonesia masih lemah. ${ }^{28}$

Lemahnya penegakan hukum di pasar modal secara signifikan akan sangat berpengaruh terhadap tingkat kepercayaan investor, tingkat investasi pemegang saham minoritas, dan kinerja pasar bursa (kapitalisasi pasar, jumlah saham, nilai saham dan indeks harga saham gabungan). Contoh kasus law enforcement pada insider trading penjualan saham BUMN di pasar modal Indonesia terjadi

\footnotetext{
${ }^{28}$ Munir Fuady, Pasar Modal Modern: Tinjauan Hukum, (Bandung: PT Citra Aditya Abadi, 2003), hlm. 4.
} 
pada penjualan saham PT Indosat Tbk pada tahun 2002.

Divestasi saham Pemerintah PT Indosat Tbk dengan cara private placement guna mendapatkan dana $1,4 \mathrm{~T}$ atau $11,32 \%$ (117 juta lembar saham) kepada investor. Transaksi ini melibatkan institusi seperti BAPPEPAM, PT Danareksa (DR) dan Credit Suisse First Boston (CSFB) sebagai penasehat keuangan Pemerintah, Merill Lynch (ML), PT Nusantara Capital (NC), Mandiri Securities (MS), ABN Amro (AA). Transaksi tersebut yang terjadi tanggal 16 Mei 2002, ternyata hanya terjual $8,1 \%$ (83,5 juta lembar saham) dengan harga Rp 12.000/saham. Kegagalan transaksi ini menimbulkan tuduhan kepada beberapa institusi seperti ML, NC, MS, CSFB maupun DR yang diduga telah melakukan transaksi melalui orang dalam atau insider trading. ML secara jelas telah melakukan tindakan ini, karena selain sebagai penasehat keuangan dalam right issue Indosat, juga bertindak dengan memberikan rekomendasi pembelian saham Indosat secara bersamaan penjualan saham tersebut pada tanggal 16 Mei 2002 (Pasal 95 dan 96 Undang-Undang Pasar Modal Nomor 8 Tahun 1995).

Manajemen Indosat telah mengeluarkan pernyataan bahwa Indosat akan melakukan right issue melalui MS sebelum korporasi private placement tanggal 16 Mei 2002, sehingga mengaburkan informasi dan mempengaruhi harga per unit saham. PT DR sebagai penasehat keuangan Pemerintah telah mengguyur pasar dengan menjual saham selama 4 hari sejak 13 hingga 16 Mei 2002, sebanyak 138 juta lembar, dicurigai sebagai insider trading (mempengaruhi pasar). Guyuran penjualan saham Indosat PT DR serta aksi jual saham oleh NC (yang memperoleh informasi dari CSFB) di samping pengumuman dari manajemen Indosat untuk right issue sebelum private placement sangat melemahkan volume dan harga jual saham menjadi hanya sekitar Rp12.000 per unit saham dan volumenya hanya mencapai $8,1 \%$ atau sebesar Rp 1 Triliun. Kelemahan UndangUndang Pasar Modal Nomor 8 Tahun 1995 pada kasus insider trading PT Indosat Tbk adalah belum diatur bila ada secondary tippe (insider masih dalam kategori traditional insider-ficudiary duty \& tippe); belum menerapkan teori penyalahgunaan (missappropriation theory), seseorang tidak harus mempunyai hubungan dari suatu ficudiary duty, tapi mengikuti kewajiban umum keterbukaan pasar modal.

Selama ini, praktik privatisasi yang dilakukan di Indonesia masih dianggap kurang optimal. Idealnya, sebelum diprivatisasi BUMN yang kurang sehat sebaiknya direstrukturisasi terlebih dahulu, sehinga pasca privatisasi nanti kinerja BUMN yang bersangkutan dapat mengalami peningkatan.

Landasan hukum privatisasi juga harus kuat, sehingga saat sebuah BUMN diprivatisasi tidak ada lagi kontroversi yang sifatnya merugikan, sedangkan dari segi politis, harus ada kesepahaman antara segenap rakyat, Pemerintah dan para pengambil kebijakan publik, sehingga semuanya sepakat bahwa privatisasi akan membawa dampak positif bagi kesejahteraan rakyat pada akhirnya kebijakan privatisasi pun didukung oleh semua pihak.

Pelaksanaan privatisasi yang belum optimal ini harus segera ditindaklanjuti. Karena sebenarnya kebijakan ini sangat terkait dengan kebijakan publik Pemerintah yang notabene akan menentukan nasib rakyat Indonesia. Padahal, jika program ini dilaksanakan dengan baik maka akan mampu membawa dampak positif bagi semua pihak. Bagi BUMN itu sendiri, akan tercapai efisiensi dan perbaikan kinerja manajemen. ${ }^{29}$ Bagi Pemerintah, privatisasi BUMN yang optimal akan sangat membantu dalam mendanai defisit anggaran 
negara, sehingga Pemerintah dapat meminimalkan pinjaman luar negeri. Akhirnya bagi rakyat Indonesia, keberhasilan privatisasi BUMN akan memperbaiki dan meningkatkan kesejahteraan rakyat karena BUMN sebagai pengelola bidang-bidang usaha vital dapat lebih memanfaatkan sumber daya vital tersebut untuk sebaik-baik kemakmuran rakyat seperti yang tercantum dalam Pasal 33 UUD Negara Republik Indonesia Tahun 1945.

\section{Kesimpulan}

Makna memperluas kepemilikan masyarakat dalam privatisasi BUMN berdasarkan Undang-Undang Nomor 19 Tahun 2003 tentang Badan Usaha Milik Negara tidak tegas (multi tafsir). Agar privatisasi sejalan dengan maksud memperluas kepemilikan masyarakat maka harus ditentukan kriterianya. Dengan tidak tegasnya makna memperluas kepemilikan masyarakat menyebabkan privatisasi tidak seperti yang digambarkan oleh Pemerintah, bertujuan untuk memperluas kepemilikan masyarakat. Namun, bukanlah masyarakat secara keseluruhan, tetapi hanya kelompok masyarakat khusus, yakni mereka yang punya uang (investor lokal atau asing) atau dengan kata lain memperluas kepemilikan pribadi bagi pemodal.

\section{Saran}

Agar privatisasi sejalan dengan maksud memperluas kepemilikan masyarakat maka sebaiknya Pemerintah membuat peraturan yang menjelaskan rumusan makna memperluas kepemilikan masyarakat dengan kriteria, yaitu orang yang merupakan Warga Negara Indonesia (WNI) atau badan yang berkedudukan dan dimiliki oleh WNI, sedangkan orang yang merupakan Warga Negara Asing (WNA) atau badan (badan asing) tidak termasuk ke dalam pengertian masyarakat. Selanjutnya metode privatisasi yang dilaksanakan Pemerintah harus konsisten dengan maksud memperluas kepemilikan masyarakat tersebut, yaitu melalui Pasar Modal dengan penjatahan yang dominan untuk kepemilikan masyarakat domestik.

\section{Referensi}

Aminuddin IImar. 2012. Hak Menguasai Negara dalam Privatisasi BUMN. Jakarta: Kencana Prenada Media Group.

A. Mukthie Fadjar. Pasal 33 UUD 1945, HAM, dan UU SDA, Jurnal Konstitusi. Volume 2. Nomor 2. September 2005.

Asropi. Menilik Kinerja Privatisasi: Perbandingan Malaysia dan Indonesia. Jurnal Administrator Borneo. Volume 4. Nomor 2. 2008.

Bacelius Ruru. Arah Kebijakan BUMN: Menghadapi Era AFTA 2003 dan APEC 2020. Jurnal Keuangan dan Moneter. BPEK. Volume 3. Nomor 1. April 1996.

Benhard Limbong. 2011. Ekonomi Kerakyatan dan Nasionalisme Ekonomi. Jakarta: Margareta Pustaka.

Burhan Ashofa. 1996. Metode Penelitian Hukum. Jakarta: Rineka Cipta.

Dewi Hanggraeni. Apakah Privatisasi BUMN Solusi yang Tepat Dalam Meningkatkan Kinerja? Jurnal Manajemen Usahawan Indonesia. Nomor 6 Tahun 2009.

Jony Ibrahim. 2006. Teori dan Metodologi Penelitian Hukum Normatif. Surabaya: Bayu Media Publishing.

Marwah M. Diah. 2003. Restrukturisasi BUMN di Indonesia Privatisasi atau

${ }^{29}$ Bacelius Ruru, Arah Kebijakan BUMN: Menghadapi EraAFTA 2003 dan APEC 2020, Jurnal Keuangan dan Moneter, BPEK, Volume 3, Nomor 1, April 1996, hlm. 11. 
Korporati-sasi. Jakarta: Literata Jendela Dunia Ilmu.

Munir Fuady. 2003. Pasar Modal Modern: Tinjauan Hukum. Bandung: PT Citra Aditya Abadi.

Safri Nugraha dkk. 2011. Privatisasi Perusahaan Milik Negara ditinjau Dari UUD 1945. Jakarta: Badan Pembinaan Hukum Nasional.
Soetandyo Wignyosoebroto. tanpa tahun. Konsep Hukum, Tipe Kajian, dan Metode Penelitiannya. Surabaya: Universitas Airlangga.

Winahyu Erwiningsih. Pelaksanaan Pengaturan Hak Menguasai Negara Atas Tanah Menurut UUD 194. Jurnal Hukum. Nomor Edisi Khusus. Volume 16 Oktober 2009. 